\title{
Alapellátás új minőségben
}

\section{Renewed primary health care in Hungary}

\author{
Szerző: Gutási Éva® \\ Nemzeti Egészségfejlesztési Intézet
}

Beküldve: 2016.08.29.

Kulcsszavak: alapellátás, gyermekek, svájci hozzájárulás, egészségfejlesztés, köznevelés

Keywords: primary care, children, swiss contribution, health promotion, public education

Az orvoslás az elmúlt két évtizedben jelentős fejlődésen ment keresztül, a magyar alapellátás múködése azonban sok esetben elmarad ettôl és nem követi a trendeket. A cél meghatározni azt, hogy miIyen változtatásokra, fejlesztésekre van szükség a következő évtizedben.

Az Alapellátás-fejlesztési Modellprogram, amely nagy hangsúlyt fektet a prevencióra, betegségmegelőzési programok, szúrések, tanácsadási és egészségfejlesztési szolgáltatások szervezésére 4 kistérségben valósul meg, 16 észak- és kelet-magyarországi településen. ${ }^{1}$ A praxisközösségi szakdolgozók együttmúködésével egy komplex, magasabb szintre emelt ellátási forma jött létre, mely az alapellátásból eddig teljesen hiányzott. Eközben szoros kapcsolat alakult ki a helyi önkormányzatokkal, oktatási és szociális intézményekkel és civil szervezetekkel. A közösségi színtereken rendezett programok a lakosság egy részében felkeltették és fenntartják az egészségtudatos életszemléletet, melynek hosszú távon is pozitív hatásai várhatók.

A praxisközösség szó a magyar egészségügyben eddig ismeretlen fogalomnak számított: maga a Modellprogram alkotta, a háziorvosok, házi gyermekorvosok, védőnők és az ő munkájukat segítő további egészségügyi szakemberek (népegészségügyi szakemberek, dietetikusok, egészségpszichológusok, gyógytornászok és praxisközösségi nővérek) csoportjának az elnevezésére, akik a modellprogram céljai megvalósítása érdekében múködnek együtt. A szakemberek munkáját orvosonként két segéd- egészségőr is támogatja, akik a helyi közösségből kerültek ki, és ezáltal könnyen, könnyebben szót tudnak érteni a lakosokkal, segítve így például a szúréseken való megjelenést, a különböző egészségprogramok népszerúsítését.

Az Alapellátás-fejlesztési Modellprogramban 2016. június 30-ig 22.000 felnőtt egészségi állapot felmérését végezték el a szűrést lebonyolító dolgozók, és több mint 9.000 gyermek rizikó- és szülői kérdőívét vették fel a védőnők. A praxisközösség munkatársai elemezték a kliensek egészségi állapotát, megbecsülték rizikófaktoraikat, feltárták a korábban nem ismert betegségeiket. A program - az új lakossági szolgáltatások bevezetésének köszönhetően - jelentős számban fedezett fel a páciensek által eddig nem ismert betegségeket, elváltozásokat: többek között magas vérnyomást, cukorbetegséget, kóros vérzsír értékeket, látászavart, mozgásszervi eltéréseket és depressziót. A szakemberek segítségével 15\%-kal csökkent a szakellátásba történő továbbutalások száma, valamint nőtt a krónikus beteggondozást igénylők körében a feltétlenül szükséges gyógyszerek kiváltásának az aránya.

A Modellprogram megvalósítása során koordinátorként arra törekszünk, hogy a praxisközösségek teljes lakosságát, így a legkisebbeket is elérjük egészségfejlesztő, prevenciós programjainkkal. Területünkön több mint tízezer gyermek él és huszonnyolc védőnő segíti a munkánkat, hogy az arra rászorulók a legmegfelelőbb segítséget kaphassák. A Projekt megvalósulása során eddig védőnőink a gyermek ri- 
zikó és szülői kérdőív felvételén túl, több mint hétszáz várandósnál végezték el az állapotfelmérést. A helyi önkormányzatokkal, intézményekkel és civil szervezetekkel együttmúködési megállapodásokat kötöttünk, így közösségeink részt vehetett többek között a helyi iskolai és óvodai egészségnapokon, falunapokon, sportnapokon, valamint gyereknapokon. A cél az, hogy az egészség fontosságával és az egészséges életmóddal kapcsolatos információkat, tudnivalókat a gyermekek ne csak megismerjék az egyes programokon, hanem tudásuk hosszútávon a mindennapi tevékenységeikbe is beépüljön. Szintén e célból jelent meg a „Minden napra egy alma” címet viselő egészségnevelő könyv is. ${ }^{2}$ A verseket, meséket olvasgatva a gyerekek akár magukra is ismerhetnek, mialatt észrevétlenül tanulnak az egészséges táplálkozásról, mozgásról, életmódról. [1. ábra és 2. ábra]

1. ábra: Óvodások a Minden napra egy alma mesekönyvvel

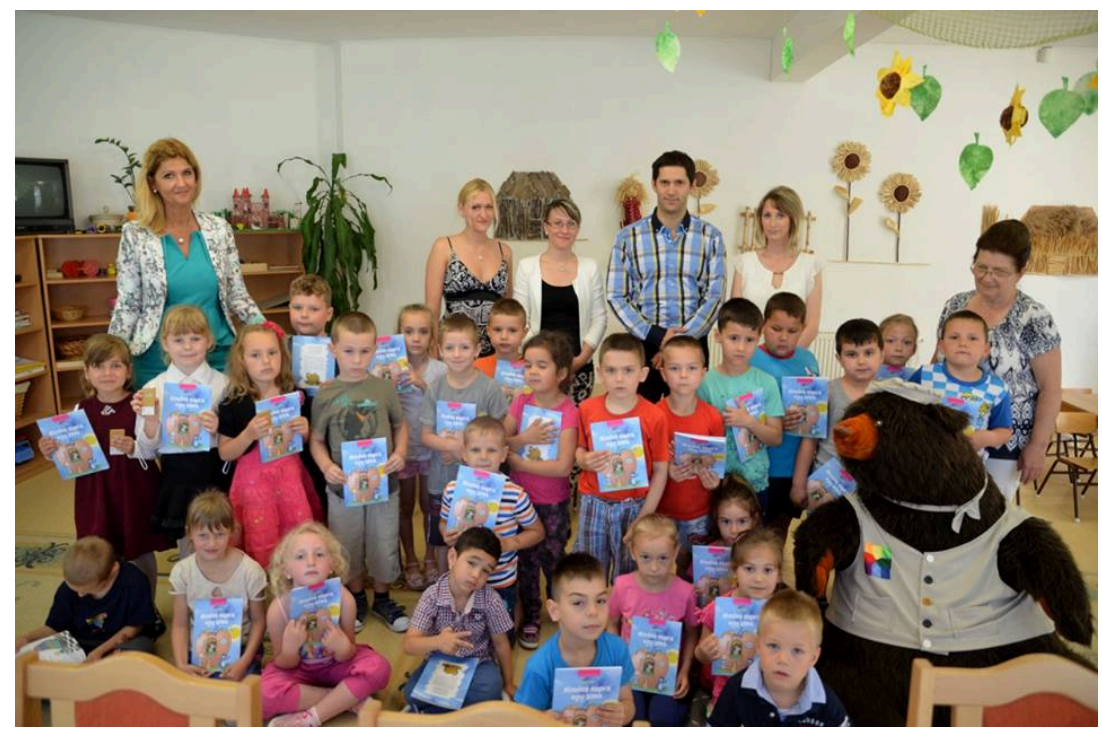

Forrás: Alapellátás-fejlesztési Modellprogram

2. ábra: Óvodások a Minden napra egy alma mesekönyvvel

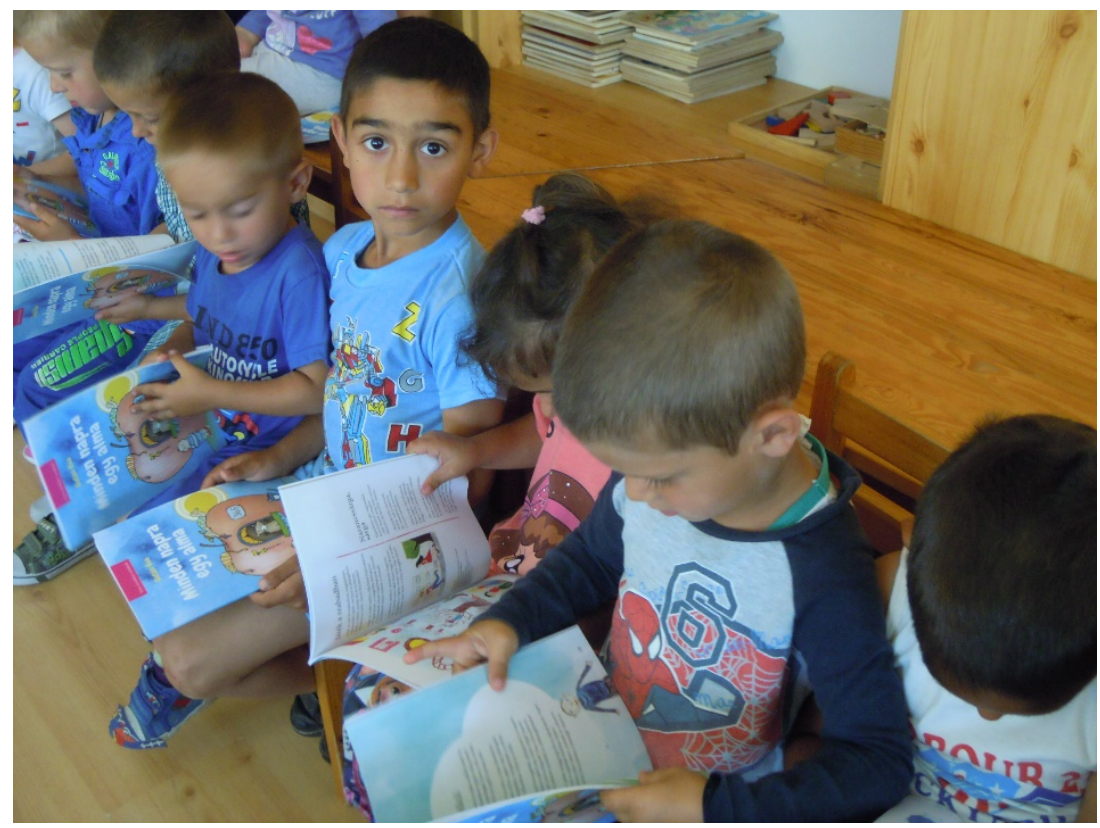

Forrás: Alapellátás-fejlesztési Modellprogram 
A Modellprogram keretében decemberben megjelenő következő, iskolásoknak szóló egészségnevelő verses-mesekönyvhöz további gyermekeket célzó kezdeményezések is kapcsolódnak, mint például a „Rajzolj te is ÁBÉCÉ-t” rajzpályázat alsós iskolások- nak, iskolás csoportoknak. ${ }^{3}$ A rajzpályázat célja, hogy a praxisközösségek iskoláiba járók képeivel illusztrálhassuk a Modellprogram új egészségnevelő könyvét. A pályázat eredményhirdetése 2016. október 12-én lesz.

\footnotetext{
${ }^{1}$ Svájci-Magyar Alapellátás-fejlesztési Modellprogram honlapja: http://www.alapellatasimodell.hu (Elérve: 2016.09.30.)

${ }^{2}$ A „Minden napra egy alma” egészségnevelő könyv az alábbi linken érhető el: http://online.fliphtml5.com/dhac/qlif/\#p=1 (Elérve: 2016.09.30.)

3 „Rajzolj te is ÁBÉCÉ-t” rajzpályázat az alábbi linken érhető el:

https://www.facebook.com/alapellatasimodell/photos/?tab=album\&album id=1080557652039928 (Elérve:

2016.09.30.)
} 